\title{
TECHNIQUES OF MARKETING LIBRARY SERVICES AND FACILITIES: A CASE STUDY OF ASHANTI REGIONAL LIBRARY
}

\author{
J. Boakye \\ Assistant Librarian, University Library \\ Kwame Nkrumah University of Science and Technology, Kumasi
}

\begin{abstract}
The paper discusses a number of techniques that are used in marketing library services and facilities. These include the use of the mass media, newsletters, leaflets, Flyers, brochures, signposts, shelf labels, catalogues (catalogue cards and Online Public Access Catalogue-OPAC) and current awareness senvices. The application of these marketing tools at the Ashanti Regional Library in Kumasi and the shortcomings observed during a survey at the library have also been discussed.

A number of suggestions towards improving the marketing of the library so as to increase its patronage have been offered.
\end{abstract}

It is hoped that maximum use will be made of the library's services and facilities if the suggestions are favourably considered.

Keywords: Marketing Techniques, Library Services, Ashanti Regional Library, Current Awareness, Guiding systems

\section{INTRODUCTION}

Techniques of marketing are the strategies adopted to attract users or customers to use a product or service. Doherty et al., (1995) considers effective marketing as involving the marketing mix which are product, place, promotion and price. The commodity the producer is offering for sale to consumers is what is referred to as the 'Product.' In marketing a commodity, there is the need to undertake marketing research to identify its potential users and where they are (i. e the 'place'). The 'promotion' aspect refers to measures undertaken to make users aware of the commodity and how to attract them to patronise it. Finally the 'price' refers to what is to be paid in purchasing the commodity or using the service involved. In determining the price, the various categories of users must be taken into consideration. For example, children and adults may not pay the same price for the commodity. The disabled and the able-bodied person may pay different prices for the same commodity. Where the commodity is sold is also one factor that determines the price. The factory price normally is lower than the price at which distributors sell the commodity. If it is sold some distance away from the factory, transportation costs may be added which will increase the price.

Dibb (1991) agrees with the marketing mix as explained above but adds 'distribution' of the commodity as another marketing factor. He notes that the selling points and distributors of the commodity as well as the packaging of the commodity must be carefully considered in marketing the commodity.

\section{The Marketing Mix in the Library}

The marketing mix can be applied in the library situation. The information provided by the library is the product while the place refers to where the potential users of the library's collections and services are identified. The promotion deals with the various activities and programmes organised to make users aware of the existence, location, collections and services offered by the library. The distribution aspects of library marketing can be looked at in terms of dissemination of information. The staff of the library are the disseminators of information and therefore can be considered as the distributors of the library's product.

\section{Guiding Systems}

A very important factor in the marketing of a library is the installation of guiding systems like signposts to inform and guide users to the location of the library. Within the library, various forms of guides are used to inform users of the available collections and services. Labels on shelves, card catalogues, online public access 
catalogues, (OPAC) printed guides, labels and directional signs which direct users to various sections, are some of the guiding systems. Higham (1987) stresses that

"The signposting of a library is a matter of the highest importance and no time or effort should be spared in making it effective"

Thompson and Carr (1987) also advise that large, clear and comprehensive signs should be provided in all key traffic areas like vestibules, lifts, lobbies and stairways stating what each floor houses and where main subjects are shelved. A display of a large plan or model of the library's layout is also a very helpful guide. A floor plan can serve in directing users to the various sections of the library. This can be placed at the issue desk to guide users as they enter the library. The signs and labels should be boldly and correctly written, kept clean and placed at the right height for easy reading.

\section{Current Awareness Services}

Current awareness services are also important library marketing tools by which users are made aware of current literature in their subject areas of interest. Hamilton (1995) defines it as: "A service which provides the recipient with information on the developments within the subject areas in which he or she has a specific interest or need to know"

She considers the following as being the main functions of a current awareness service:

1. It enables the information staff to learn the individual needs of the users.

2. It provides a valuable information service to those users

3. It promotes the library or information centre by drawing the attention of its potential users to its existence

There are a number of methods of making users aware of the current literature on their subjects of interest. These include the circulation of periodicals (with articles of interest) among users, and making photocopies of content pages for users. Newlyacquired books and journals could also be made known to them.

To know users, their specific needs and how to contact them, the librarian ar.j staff must have what is called 'User Profile.' Users can be given questionnaires to fill providing information on themselves. The information requested for, could cover the following: a. Name of user

b. Telephone/Fax number

c. Postal Address:

i. Office address

ii. Residential address

iii. E-mail address

d. Profession

e. Subject Interest

f. Newspapers and Journals of interest

g. Research Topics

\section{The Ashanti Regional Library}

\section{Survey}

A survey was undertaken of the Ashanti Regional Library in September 2002 with the aim of finding out the extent to which marketing techniques as discussed above are applied to make users aware of and so use its collections and services.

\section{Brief History}

In its Silver Jubilee Brochure, Ghana Library Board (1975) gives the historical development of public library services in Ghana. According to the Board, the public library services began before 1950 , but not supervised by a national board. To make the public library services well organised and effectively administered, the Gold Coast (later Ghana) Government decided to set up a Board to see to the organisation of the services. In December 1949 the Legislative Council of the Gold Coast passed the Gold Coast Ordinance, Cap 118 which came into operation on $1^{\text {tt }}$ January 1950.

Among the Board's operations was the establishment of Regional Libraries, one of which was the Ashanti Regional Library which was opened on $30^{\text {th }}$ June 1954.

\section{Profile of the Library}

\section{Location}

It is located at the Centre for National Culture, Kumasi

\section{Staff}

It has a staff of 15, made up of the Regional Librarian and his deputy, three Library Assistants, eight Junior Library Assistants, one Secretary and one Accounts Clerk. Only the Regional Librarian and his Deputy are professional Librarians.

44 journal of science and technology, volume 23 no.1 2003 
Opening Hours

The library is opened to the general pubic from Monday to Saturday. The opening hours are: $\begin{array}{ll}\text { Monday to Friday: } & 9.00 \mathrm{am}-6.00 \mathrm{pm} \\ \text { Saturday: } & 9.00 \mathrm{am}-2.00 \mathrm{pm}\end{array}$

\section{Sections and Services}

It has three Sections: Lending, Reference and Children's Library. Lending services are offered at the Lending and Children's Library while the Reference Section offers reference services. The Lending services are offered to the registered users of the library. The registration rates are as follows:

Primary School Children - $\notin 2,000.00$ per annum Junior Sec. Sch. students - $\$ 3,000.00$ per annum Senior Sec. Sch. students - $\$ 5,000.00$ per annum Adults

$$
\text { - } \quad 10,000.00 \text { per annum }
$$

The children can borrow one book for two weeks and this can be renewed for another two weeks, while the students and adults can borrow three books for three weeks and renewed for another three weeks.

\section{Users}

The library is patronised by the general public, especially students and teachers in and around Kumasi.

\section{Seating capacity}

Seating facilities have been offered at the Reference and Children's Library. The Reference Section has a seating capacity of 100 while the Children's Library can accommodate 48 users at a time. There are no chairs and tables at the Lending Section for use by readers.

\section{Bookstock}

The three sections of the library had a total bookstock of 41,067 volumes as at $26^{\text {th }}$ September 2002 . The children's library had 15,070 volumes while the Lending and Reference Libraries together had 25,997 volumes.

Being a public library, its collections cover a wide range of subjects to meet public reading interest. At the Reference and Lending Sections there are books on History, Literature in English, Accounting, Management, Medical Sciences, Biology, Physics, Chemistry, Geography, Economics, Government, Sociology, Ghana Law Reports, Psychology, Physiology, and Languages - French, Spanish, English and Ghanaian Languages. The Reference Section stocks a special collection on Ghana. The collections at the Children's Library include fiction and school textbooks.

The unfortunate thing about these collections is that many of them are outdated. However there were some new books being processed to be added to those on the shelves. The processing needs to be speeded up so that they would replace the outdated ones.

\section{Newspapers and Journals}

Six local newspapers are subscribed. Very few journals are available.

\section{Marketing Techniques}

It was observed that some measures have been taken towards marketing the library and its collections. However there is much room for improvement.

\section{External Signposts}

There are no external signposts installed to inform and guide users to the library. There is the need to install one at the main entrance leading to the Centre for National Culture where the Library is located. At the Centre itself a signpost must be installed on the road leading to the library.

\section{Library Building and its Environment}

The physical appearance of the library and its internal facilities play a very important role in attracting users to patronise it.

At the Ashanti Regional Library the lighting system and ventilation are good but then the building needs refurbishment. The walls need to be re-painted and the roofing which is in very bad shape needs repairs. At the time of the survey the surroundings were neatly kept. It is hoped the clean environment will be maintained.

\section{Internal Guiding System}

\section{Doorposts}

The internal guiding systems help users to find their way about when they are within the library's premises. Labels will guide the users to know where the various sections are. Of the three sections at the Library only the Lending Section has a label on the doorpost at the entrance of the Section. The other two (Reference and Children's library) are without labels 


\section{Shelf Labels}

Many of the shelves in all the three sections have been labelled to guide users in their information retrieval Some of the labels are however not boldly written. New labels which are more conspicuous should replace them.

\section{Class Numbers}

The books have been classified according to the Dewey Decimal Classification Scheme. Most of the books have class numbers.

\section{Catalogue Cabinet}

The catalogue cards have been filed in a wooden catalogue cabinet and placed at the Lending Section.

\section{New Additions}

Newly-acquired books are displayed on a shelf placed at the Lending Section. The shelf must be labelled.

\section{Suggestions for Improving the Library's}

\section{Marketing Techniques}

As earlier stated a lot needs to be done in marketing the services of the library which can lead to increase in patronage. The suggestions below are offered towards improvement in the marketing of the Ashanti Regional Library.

\section{Refurbishment}

The building does not look attractive to patrons. The walls need to be re-painted to give the library a new look. The roofing of the building is not in good shape. It was observed that there are leakages in the roof. The Ghana Library Board must source for funding for rehabilitation. The Board can appeal to the Ghana Education Trust Fund and the Otumfuo Education Fund for financial assistance.

\section{Signposting}

Signposts must be installed at the main entrance of the Centre for National Culture so that passers-by will become aware of the existence of the library at the Centre. Another signpost must be installed at the main road at the centre which leads to the Library.

\section{Internal Guiding System}

The labels on all the shelves must be boldly written to make them more conspicuous. There should be labels at the entrances of all the three sections to inform users of the services offered at those sections.

\section{Public Awareness Promotion}

According to the former Librarian, up to the year 2000 the library used to organise programmes by which schools were engaged in competitions which made many students and tcachers aware of the collections and scrvices. The competitions were in the form of debates, quiz and spelling bee. These attracted a lot of school children, teachers and members of the general public to the library's premises which could be considered as a form of public awareness promotion. This programme nceds to be revived in order to increase the patronage of the library.

\section{Readers Clubs}

In the past there used to be Readers Clubs organised by the Library which encouraged many users to read many books at the library. There is the need to reorganise the clubs which will help many users to improve upon their reading skills. The formation of the Readers Clubs was a major marketing technique as members of the clubs informed other people of the collections of the library.

\section{Information to Schools}

Lists of newly-acquired books must be compiled and copies sent to schools and colleges in Kumasi in particular and the Ashanti Region in general. The lists could be given to the Kumasi Metropolitan Education Office and the Regional Education Office to be distributed to schools. Copies of the lists could be posted on the Library's notice boards to inform the general public.

\section{Current Awareness Services}

The profiles of registered users must be compiled covering their addresses and subject interests so that they could be informed of newly-acquired books and journals which will be of interest to them. For example, lawyers could be informed of newly-acquired law books, doctors and nurses could be informed of the newly-acquired medical books while teachers are also informed of books in their subject areas that are available at the library.

\section{Advertising}

The public and private FM radio stations could be used in marketing the library's services and facilities. Sponsorship could be sought by the Ghana Library Board from the Ministry of Education and other Agencies. The Board should also make provision in its budget for such announcements. Newsletters and flyers with brief information on the library could be 
prepared and distributed to the general public. Some could be sent to public and private schools around. The rest could be sent to the Post Office and put in letter boxes as it is done by some commercial organizations.

\section{Staff Turnover}

According to the Deputy Librarian who was interviewed there is a high staff turnover due to unsatisfactory conditions of service which affects the library's services to the public and this negatively affects its patronage. The Government must endeavour to improve upon the conditions of service so that the experienced members of staff would stay to offer the services needed to encourage patrons to continue patronising the library.

\section{Children's Library}

The Children's library which has a seating capacity of 48 had only two tables (at the time of the survey) that can accommodate only eight readers. Additional tables and comfortable chairs must be provided to make the library attractive to the children.

\section{Lending Section}

There are no tables and chairs at the Lending Section for use by readers. Even though only Lending services are offered some users would like to sit down and read a few pages of books they would like to borrow before deciding finally whether to borrow them or not. If such readers feel comfortable at the place they will encourage others to register and patronise the library. It is therefore suggested that tables and chairs should be provided to seat about 20 readers.

\section{Old Books}

Many of the books are quite old and need to be replaced with current ones. Processing of the newlyacquired books must be speeded up and put on the shelves, so as to attract more users to patronise the library.

\section{Conclusion}

The Ashanti Regional Library plays a key role in the provision of Library services in the Ashanti Region. If it is to be effectively used to the maximum, its services and facilities must be made well known to the public so as to increase its patronage. The marketing techniques discussed and the suggestions made will go a long way in increasing the patronage of the library if they are seriously considered and applied.

\section{References}

1. Dibb, S. (1991). Marketing concepts and strategies. London: Houghton, Miflin 220p. pl6

2. Doherty, N.F., Saker, J. and Smith, I.G. (1995). "Marketing development in the public library sector: an empirical analysis". Journal of Information Science 21(6), 449-458.

3. Ghana Library Board (1975). The Ghana Library Board Silver Jubilee 1950 - 1975. Accra: Select Publications and Promotions. Xv, 115 pp. 9, 13 and 103

4. Hamilton, F. (1995). Current awareness, current techniques. Aldershot, Hampshire: Gower Publishing. Xii, 175pp.10

5. Higham, N. (1987). The library in the university: observations on a service quoted by James Thompson and Reg Carr In An introduction to university library administration $4^{\text {th }}$ ed. London: Clive Bingley, vi, 265pp 178

6. Thompson, J. and Carr, R. (1987). An introduction to university library administration $4^{\text {th }}$ ed. London: Clive Bingley vi, 265p p.2 